\section{Social Science Research Council}

Is a written answer in the House of Commons on November 2, Mr. A. Crosland, Secretary of State for Education and Science, stated that further to the appointment of Dr. M. Young as chairman of the Social S'cience Research Council, the following members of the Council had also been appointed: W. O. C. Adamson, A. L. C. Bullock, Prof. J. Drever, Prof. R. W. Firth, Sir William O. Hart, Prof. Marie Jahoda, Lord James of Rusholme, Prof. R. G. Lipsey, Prof. W. J. M. Mackenzie, Prof. T. H. Marshall, Prof. C. A. Moser, L. Murray, Prof. R. M. Titmuss and G. D. N. Worswick. A draft of the Charter to be granted to the Council has been approved by Her Majesty in Council, and a draft Order specifying the objects of the new body and declaring it to be a Research Council for purposes of the Science and Technology Act, 1965, has been laid before Parliament.

\section{Desalination of Sea-water}

Is a written answer in the House of Commons on October 27, Mr. F. Cousins, the Minister of Technology, stated that the Atomic Energy Authority and industry had completed a design for a plant to produce 30 million gallons of fresh water a day from sea-water. Further design work had been done, particularly in respect of dualpurpose plants for producing electric power and fresh water from nuclear reactors, and economic studies on these plants had been made in some detail. The great contribution already made by Britain had been recog. nized at the recent international conference on desalination in Washington. More than two-thirds of all landbased desalination capacity in the world, including the biggest sea-water distillation plant at Kuwait, with a capacity of 1.4 million gallons a day, was built by British industry. Much interest was also shown at the Washington conference in Britain's design studies for combined power and distillation plants. In conjunction with Weir Wostgarth and the nuclear engineering industry, the Authority had done much to improve the steam cycle of these dual-purpose plants. The flash-distillation process remained the most promising process so far available, and every effort was being made to improve its technical and economic efficiency. Work had also been started on alterna. tive processes, such as reverse osmosis and electrodialysis, which might become increasingly important.

\section{Research and Development in the Building and Civil Engineering Industries}

Is a written answer in the House of Commons on November 1, Mr. C. Pannell, the Minister of Public Building and Works, stated that during the past 9 months the Directorate General of Research and Development had made a comprehensive review of research and development related to the building and civil engineering industries. It had commissioned from universities some research projects relevant to the construction industry and was studying proposals for increasing the resources available for building research and the dissemination of technical information in the industry. Design work had started on a $£ 1$ million pre-production programme for the Department's steel-framed system, Nenk. Further progress had beon made with dimensional co-ordination and a start had been made on the change to the metric system. The Department had continued its work on winter building and had issued a film on techniques suitable for smaller buildors. It continued to collect, analyse and disseminate statistical information, and to advise on the construction industries in connexion with the Government's economic planning. The Ministry was represented on the Economic Development Committees for the civil engineering and building industries by members of the Directorate.

\section{Solway Firth Barrage}

In answer to a question in the House of Commons on November 3, Mr. W. Ross, the Secretary of State for Scotland, said that, as a result of the moratorium on capital expenditure announced in July, it was not possible to procoed immediately with the full-scale feasibility study of the Solway Firth Barrage. However, axrangements had been made for Messrs. Babtie, Shaw and Morton to start a preliminary study, costing some $£ 10,000-£ 15,000$, on the quantity and quality of water that would be made available by a barrage.

\section{Second Conference on the Countryside in 1970}

WHEN the Duke of Edinburgh inspected National Nature Week in May 1963, what impressed. him most was that so much goodwill and so many bodies interested in the care of the countryside were meeting with so little success in saving it. This he attributed to a lack of thorough enquiry and clear thinking which might enable all concernod to work in harmony and produce early and worth-while results. At his initiation, a study conference with that object was convened. It was felt that the countryside was in grave danger of irreparable damage by 1970. The first study conference in November 1963 brought the parties together, obtained fairly widespread agreement and helped towards resolving certain special problems such as the misuso of toxic ehemicals on the land (Nature, 201, 958; 1964). It could not, however, tacklo many deeper and more complex probloms which needed more time and manpower.

This task has now been undertaken by twelve study groups and a number of other combined operations, and the results camo before the second study conference opened by the Duke of Edinburgh on November 10 at the Royal Society of Arts. That day and the next were devoted to intensive examination by those responsible for preparing the conference documents with the view of bringing them together as a whole and defining ways and means of obtaining positivo action. At this stage, Lord Strang, chairman of the National Parks Commission, and Lord Robens, chairman of the National Coal Board, took the chair in turn. On November 12 the final reports went to a larger plenary meeting at Fishmongers' Hall, at which Mr. F. Willey, the Minister of Land and Natural Resources, made a policy statement on behalf of the Government. Spokesmen of other national interests included Mr. John Davies for the Confederation of British Industries, Prof. C. Buchanan on "Road Use in the Countryside", Mr. Jack Longland on education, Mr. W. Doedes on "Information", and Mrs. G. L. S. Pike of the National Federation of Women's Institutes, speaking from the point of view of the country dweller.

The conference was sponsored by the Royal Society of Arts, the Nature Conservaney and the Council for Nature.

\section{Central Building Research Institute, Roorkee, India}

Ir is always a matter of interest to students of building technology to learn, if only for comparative purposes, of the progress of research and of various lines of enquiry pursued in this field by organizations similar to the British Building Research Station, which have been established in other countries. India is no exception to this, as is elear from the annual report of the Central Building Research Institute, 1964-65 (India: Council of Scientific and Industrial Research. Pp. ix +83 . Roorkee (U.P.): Central Building Research Institute, 1965). In his foreword, G. Pande, chairman of the Executive Council of the Central Building Research Institute, makes these points: ". . . the trend of research in the Institute has been project oriented and greater emphasis has been given during the year on projects which have immediate impact on the building industry by way of increasing 